\title{
Penentuan Faktor-Faktor Pemilihan Park \& Ride Sebagai Fasilitas Pergerakan Komuter Pada Koridor Bekasi-Jakarta
}

\author{
M Faridz Nazalaputra dan Ketut Dewi Martha Erli Handayeni \\ Jurusan Perencanaan Wilayah dan Kota, Fakultas Teknik Sipil dan Perencanaan, Institut Teknologi Sepuluh Nopember (ITS) \\ Jl. Arief Rahman Hakim, Surabaya 60111 Indonesia \\ e-mail: fnazalaputra@gmail.com
}

\begin{abstract}
Abstrak-Kemacetan di DKI Jakarta terjadi karena adanya mobilitas penduduk JABODETABEK yang menggunakan kendaraan pribadi menuju DKI Jakarta setiap hari. Park \& ride merupakan sebuah fasilitas penunjang moda transportasi KRL yang dapat mengalihkan pengguna pribadi untuk menggunakan moda transportasi KRL. Dalam optimalisasi fasilitas park \& ride, perlu dilakukan penelitian untuk mencari faktor-faktor yang mempengaruhi penggunaan park \& ride pada Koridor Bekasi-Jakarta.

Dengan menggunakan teknik analisis crosstab dan korelasi bivariat, dihasilkan faktor-faktor yang mempengaruhi pemilihan park \& ride sebagai fasilitas pergerakan komuter pada Koridor Bekasi-Jakarta. Faktor-faktor yang memiliki pengaruh signifikan terhadap pemilihan park \& ride sebagai fasilitas pergerakan komuter pada Koridor Bekasi-Jakarta adalah faktor biaya parkir, lama parkir, kenyamanan fasilitas parkir, jenis pekerjaan, maksud perjalanan, waktu tempuh KRL, jarak tempat tinggal menuju stasiun asal, jarak tempuh KRL, biaya perjalanan dan penggunaan moda pada stasiun pemberhentian. Dari 10 faktor tersebut, faktor maksud perjalanan memiliki nilai korelasi paling besar terhadap pemilihan park \& ride sebagai fasilitas pergerakan komuter.
\end{abstract}

Kata Kunci-Park \& Ride, Faktor Pengaruh

\section{PENDAHULUAN}

$\mathrm{T}$ RANSPORTASI merupakan salah satu aspek yang berperan vital dalam berkembangnya suatu kawasan perkotaan. Perkembangan kota menyebabkan mobilitas seseorang meningkat sehingga perlu adanya prasarana transportasi yang dapat menunjang kebutuhan pergerakannya. Transportasi memiliki dua peran utama, yaitu sebagai alat bantu untuk mengarahkan pembangunan di daerah perkotaan dan sebagai prasarana bagi pergerakan manusia dan/atau barang yang timbul akibat adanya kegiatan di daerah perkotaan tersebut.

Pembangunan DKI Jakarta memicu perkembangan kegiatan perkotaan wilayah - wilayah di sekitar Jakarta yaitu Bogor, Depok, Tangerang, dan Bekasi (BODETABEK). Mahalnya harga permukiman yang ada di Jakarta menyebabkan terjadinya proses densifikasi permukiman di daerah BODETABEK. Hal ini menyebabkan peningkatan mobilitas penduduk BODETABEK sebagai sub urban menuju pusat kegiatan DKI Jakarta. Mobilitas yang terjadi pada wilayah JABODETABEK menyebabkan bertambahnya jumlah penduduk DKI Jakarta pada siang hari sebesar 1.126.310 jiwa. Jumlah komuter terbanyak berasal dari kota Bekasi yaitu sebanyak 460.069 jiwa atau $33.3 \%$ dari jumlah komuter keseluruhan [3].

Komuter merupakan seseorang yang melakukan aktivitasnya di luar kabupaten/kota tempat tinggal dan secara rutin pergi dan pulang (PP) ke tempat tinggalnya pada hari yang sama. Salah satu angkutan massal yang cukup efisien untuk melayani penduduk komuter JABODETABEK adalah KRL. Angkutan ini dapat mengangkut komuter dalam jumlah banyak dan menempuh jarak jauh dalam waktu yang relatif cepat. Saat ini, terdapat 6 rute utama KRL yang melayani pergerakan di wilayah JABODETABEK yaitu Tangerang Duri, Maja/Parung Panjang/Serpong - Tanah Abang, Bogor/Depok - Jatinegara, Bogor/Depok - Jakarta Kota, Bekasi - Jakarta Kota dan Tanjung Priok - Jakarta Kota [2].

KRL koridor Bekasi - Jakarta melewati 15 stasiun yakni stasiun Bekasi, Kranji, Cakung, Klender Baru, Buaran, Klender, Jatinegara, Manggarai, Cikini, Gondangdia, Juanda, Sawah Besar, Mangga Besar, Jayakarta dan Jakarta Kota. Dari 460.069 jiwa jumlah komuter yang ada di Bekasi, hanya 31.373 jiwa yang memilih KRL sebagai moda transportasi utama yang digunakan untuk melakukan aktivitas, sedangkan jumlah pengguna kendaraan pribadi atau single occupancy vehicle (SOV) berjumlah 331.244 jiwa [2]. Besarnya jumlah komuter Kota Bekasi yang menggunakan SOV merupakan salah satu faktor yang menyebabkan kemacetan di JABODETABEK. Guna memaksimalkan tingkat pelayanan $\mathrm{KRL}$, park and ride merupakan salah satu solusi untuk menarik pengguna SOV untuk menggunakan KRL yang merupakan high occupancy vehicle (HOV).

Park and ride merupakan sistem transportasi yang menggunakan fasilitas ruang parkir dengan menitipkan kendaraan pribadi, kemudian beralih ke moda transportasi umum [14]. Fasilitas park and ride sangat bergantung terhadap dengan sistem transportasi umum. Artinya park and ride merupakan salah satu fasilitas penunjang tempat pemberhentian/transit seperti terminal atau stasiun KRL yang berfungsi sebagai penarik pengguna kendaraan pribadi untuk menggunakan transportasi publik yang memiliki kapasitas angkut yang lebih besar [13].

Penerapan park and ride merupakan strategi yang efektif untuk meningkatkan pelayanan transportasi berbasis transit. 
Namun, infrastruktur parkir stasiun sepanjang Koridor Bekasi - Jakarta belum memberikan kenyamanan para pelaku komuting. Di sisi lain PT KCJ menargetkan pada tahun 2016 jumlah pengguna KRL pada Koridor Bekasi - Jakarta meningkat sebesar 107.680 penumpang. Potensi pengguna park and ride pada Stasiun KRL Koridor Bekasi - Jakarta cukup tinggi, namun dengan kondisi eksisting yang ada membuat fungsi park and ride pada Stasiun KRL Koridor Bekasi Jakarta belum optimal. Untuk mengoptimalkan sistem transportasi terutama KRL koridor Bekasi - Jakarta, maka perlunya kajian mengidentifikasi faktor - faktor yang mempengaruhi komuter untuk menggunakan fasilitas park and ride sebagai penunjang pergerakan dengan moda kereta.

\section{METODE PENELITIAN}

\section{A. Jenis dan Pendekatan Penelitian}

Pendekatan yang digunakan dalam penelitian ini adalah pendekatan positivistik. Jenis penelitian dalam penelitian ini adalah deskripti kuantitatif.

\section{B. Variabel Penelitian}

Variabel yang digunakan pada penelitian ini adalah sebagai berikut [1] [4] [6] [7] [8] [9] [10] [11] [12] [13] [14] [15] [16]:

Tabel 1.

Variabel Penelitian

\begin{tabular}{|c|c|c|}
\hline Indikator & Variabel & Sub Variabel \\
\hline \multirow{8}{*}{$\begin{array}{l}\text { Karakteristik } \\
\quad \text { Parkir }\end{array}$} & Biaya Parkir & - \\
\hline & Kemudahan Memperoleh & \\
\hline & Parkir & \\
\hline & Pengelola Parkir & - \\
\hline & Lama Parkir & - \\
\hline & & Kenyamanan Fasilitas \\
\hline & & Parkir \\
\hline & Kenyamanan Parkir & $\begin{array}{l}\text { Ketersediaan Pedestrian } \\
\text { Way (menghubungkan } \\
\text { tempat parkir dengan } \\
\text { stasiun) }\end{array}$ \\
\hline \multirow{6}{*}{$\begin{array}{c}\text { Karakteristik } \\
\text { Sosial } \\
\text { Ekonomi }\end{array}$} & Keamanan Parkir & - \\
\hline & Jenis Kelamin & - \\
\hline & Pendapatan & - \\
\hline & Tingkat Pendidikan & - \\
\hline & Jenis Pekerjaan & - \\
\hline & Maksud Perjalanan & - \\
\hline \multirow{13}{*}{$\begin{array}{l}\text { Karakteristik } \\
\text { Perjalanan }\end{array}$} & Waktu Perjalanan & $\begin{array}{l}\text { Waktu Menuju Stasiun } \\
\text { Asal }\end{array}$ \\
\hline & & Waktu Perjalanan Moda \\
\hline & & $\begin{array}{l}\text { KRL } \\
\text { Waktu Menuju Lokasi } \\
\text { Tujuan }\end{array}$ \\
\hline & Panjang Perjalanan & Jarak Menuju Stasiun Asal \\
\hline & & Jarak Tempuh KRL \\
\hline & & Jarak Menuju Lokasi \\
\hline & Biaya Perialanan & I ujuant \\
\hline & Jumlah Moda Transportasi & \\
\hline & Umum yang Tersedia & - \\
\hline & Penggunaan Moda Pada & \\
\hline & Stasiun Pemberhentian & 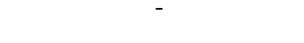 \\
\hline & Pedestrian Way (pada & $\begin{array}{l}\text { Ketersediaan Pedestrian } \\
\text { Way }\end{array}$ \\
\hline & stasiun pemberhentian) & Kondisi Pedestrian Way \\
\hline
\end{tabular}

Sumber: Penulis, 2016

\section{Metode Analisis}

Teknik analisis yang digunakan dalam penelitian ini adalah sebagai berikut:

1) Teknik Analisis Statistik Deskriptif

Teknik analisis statistik deskriptif merupakan penerapan metode statistik untuk mengumpulkan, mengolah, menyajikan, dan menganalisis data kuantitatif secara deskriptif. Analisis statistik deskriptif digunakan untuk mengidentifikasi karakteristik parkir pada Koridor Bekasi-Jakarta dan mengidentifikasi perilaku pergerakan komuter yang menggunakan fasilitas park \& ride. untuk mendapatkan data, diperlukan penyebaran kuesioner dengan sampel pengguna park \& ride pada Stasiun Bekasi dan Kranji.

\section{2) Crosstab dan Korelasi Bivariat}

Metode tabulasi silang dan kolerasi bivariat digunakan untuk mengetahui keterkaitan atau hubungan antar variabel penelitian. Pada tahap analisis ini terdapat variabel dependen yaitu frekuensi para komuter dalam menggunakan park \& ride dalam 1 minggu (5 hari kerja) dan variabel independen berdasarkan 3 indikator pada penelitian ini yaitu (1) Karakteristik Parkir (2) Karakteristik Sosial-Ekonomi dan (3) Karakteristik Perjalanan.

Alat analisis crosstab dan korelasi bivariat membutuhkan hipotesis untuk menguji keterkaitan antar variabel [5]. Hipotesis pada analisis faktor-faktor yang mempengaruhi penggunaan park \& ride pada Koridor Bekasi-Jakarta adalah sebagai berikut:

Ho : Tidak ada hubungan antara frekuensi penggunaan park \& ride dengan karakteristik parkir, karakteristik sosial-ekonomi, dan karakteristik perjalanan pelaku komuting.

$\mathrm{Ha}$ : Ada hubungan antara frekuensi penggunaan park \& ride dengan karakteristik parkir, karakteristik sosial-ekonomi dan karakteristik perjalanan pelaku komuting.

Pada tahap analisis ini, uji hipotesis dilakukan dengan melihat nilai signifikansi. Untuk analisis korelasi bivariat, uji hipotesis dapat dilakukan dengan melihat nilai signifikansi. Berikut dasar pengambilan keputusan hipotesis pada analisis crosstab dan korelasi bivariat:

Nilai sig > 0,05, maka Ho diterima

Nilai sig $<0,05$, maka Ho ditolak

Setelah menghitung nilai signifikansi, analisis dilanjutkan dengan menghitung nilai koefisien kontingensi (korelasi). Nilai korelasi akan menentukan tingkat kekuatan hubungan antara variabel independen dan dependen. Setelah menghitung nilai chi-square dan nilai signifikansi, analisis dilanjutkan dengan menghitung nilai koefisien kontingensi. Nilai koefisien kontingensi akan menentukan seberapa kuat hubungan antara variabel independen dan dependen. Pedoman untuk memberikan interpretasi koefisien kontingensi sebagai berikut: 
Tabel 1.

Pedoman Umum dalamMenentukan Kriteria Korelasi

\begin{tabular}{cc}
\hline Nilai & Kriteria \\
$0-0,199$ & Sangat Rendah \\
$0,2-0,399$ & Rendah \\
$0,4-0,599$ & Sedang \\
$0,6-0,799$ & Kuat \\
$0,8-1$ & Sangat Kuat \\
\hline \hline
\end{tabular}

\section{HASIL DAN DISKUSI}

A. Identifikasi karakteristik parkir yang tersedia pada stasiun asal (Bekasi dan Kranji) KRL Koridor Bekasi-Jakarta

Stasiun Bekasi terletak di Kelurahan Margamulya Kota Bekasi. Pada Stasiun Bekasi terdapat dua jenis pengelola parkir yaitu parkir yang dikelola oleh PT Reska Multi Usaha (RMU) dan parkir yang dikelola oleh masyarakat setempat. Parkir yang dikola oleh masyarakat menawarkan biaya yang lebih murah bila dibandingkan dengan parkir PT RMU. Namun akses parkir yang dikelola oleh masyarakat menuju stasiun lebih sulit karena letak parkir diluar area stasiun. Berbeda dengan parkir yang dikelola oleh PT RMU yang terletak didalam area stasiun.

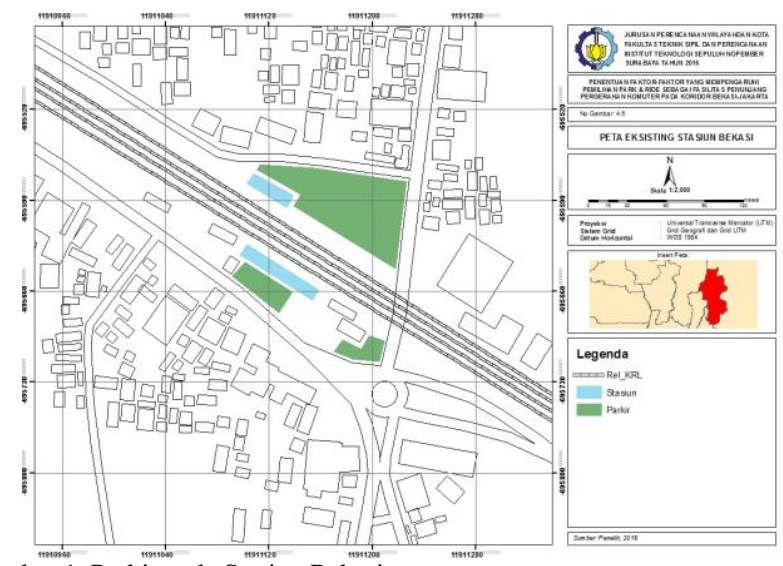

Gambar 1. Parkir pada Stasiun Bekasi

Sumber: Survey Primer, 2016

Stasiun Kranji terletak di Kelurahan Kranji Kota Bekasi. Tidak ada perbedaan yang besar antara karakteristik parkir pada Stasiun Bekasi dan Stasiun Kranji. Namun kondisi akses parkir yang dikelola oleh masyarakat pada sisi utara menuju stasiun pada Stasiun Kranji sangat buruk karena belum mengalami perkerasan (masih jalan tanah).

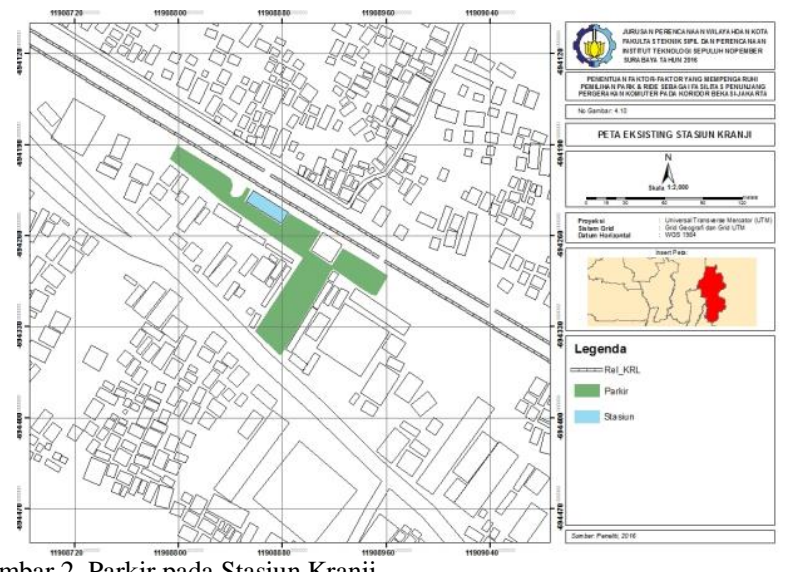

Gambar 2. Parkir pada Stasiun Kranji

Sumber: Survey Primer, 2016

Berdasarkan hasil kuesionerKarakteristk parkir yang tersedia pada Stasiun Bekasi dan Kranji didapatkan berdasarkan hasil kuesioner yang disebar kepada para pengguna park \& ride yang berasal dari Stasiun Bekasi dan Kranji. Berikut karakteristik parkir pada Stasiun Bekasi dan Kranji.

Tabel 3.

Karakteristik Parkir pada Stasiun Asal

\begin{tabular}{|c|c|c|}
\hline Variabel & Sub-Variabel & Deskripsi \\
\hline Biaya Parkir & 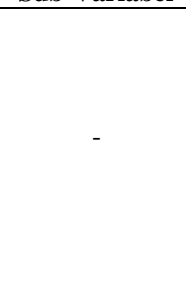 & $\begin{array}{l}\text { Sebanyak } 38,41 \% \text { responden } \\
\text { mengeluarkan biaya parkir } \\
\text { sebesar kurang dari Rp. } 5.000 . \\
\text { Sehingga dapat disimpulkan } \\
\text { bahwa responden yang } \\
\text { menggunakan fasilitas park \& } \\
\text { ride cenderung memilih biaya } \\
\text { parkir yang paling murah. } \\
46,36 \% \text { responden pada Stasiun }\end{array}$ \\
\hline $\begin{array}{l}\text { Kemudahan } \\
\text { Memperoleh } \\
\text { Parkir }\end{array}$ & - & $\begin{array}{l}\text { Bekasi dan Kranji berpendapat } \\
\text { mudah untuk memperoleh parkir. } \\
\text { Artinya adalah fasilitas parkir } \\
\text { yang tersedia pada stasiun asal } \\
\text { telah memberikan kenyamanan } \\
\text { kepada pelaku komuting dalam } \\
\text { memperoleh parkir. }\end{array}$ \\
\hline Pengelola Parkir & - & $\begin{array}{l}\text { Apabila dibedakan dari jenis } \\
\text { kendaraannya, responden yang } \\
\text { menggunakan sepeda motor } \\
\text { cenderung memilih memarkirkan } \\
\text { kendaraan mereka di tempat } \\
\text { parkir yang dikelola oleh } \\
\text { masyarakat } 57,55 \% \text { responden). } \\
\text { Hal ini disebabkan karena tempat } \\
\text { parkir yang dikelola oleh } \\
\text { masyarakat memperikan } \\
\text { kenyaman parkir yang baik } \\
\text { dengan menawarkan biaya parkir } \\
\text { yang lebih murah. }\end{array}$ \\
\hline Lama Parkir & - & $\begin{array}{l}\text { Sebanyak } 74,14 \% \text { responden } \\
\text { memarkirkan kendaraan mereka } \\
\text { di tempar parkir yang tersedia } \\
\text { pada stasiun asal selama } 7-12 \text { jam. }\end{array}$ \\
\hline $\begin{array}{l}\text { Kenyamanan } \\
\text { Parkir }\end{array}$ & $\begin{array}{l}\text { Kenyamanan } \\
\text { FasilitasParkir }\end{array}$ & $\begin{array}{l}\text { Sebanyak } 50,99 \% \text { responden } \\
\text { berpendapat kenyamanan fasilitas } \\
\text { parkir pada stasiun asal sudah } \\
\text { cukup baik. }\end{array}$ \\
\hline & $\begin{array}{l}\text { Kenyamanan } \\
\text { pedestrian way } \\
\text { parkir }\end{array}$ & $\begin{array}{l}\text { Sebanyak } 41,08 \% \text { responden } \\
\text { berpendapat tingkat kenyamanan } \\
\text { pedestrian way sudah baik. }\end{array}$ \\
\hline $\begin{array}{l}\text { Keamanan } \\
\text { Parkir }\end{array}$ & - & $\begin{array}{lrl}\text { Sebanyak } & 59,60 \% & \text { responden } \\
\text { berpendapat } & \text { tingkat } & \text { keamanan }\end{array}$ \\
\hline
\end{tabular}




\begin{tabular}{ccc}
\hline \hline Variabel & Sub-Variabel & \multicolumn{1}{c}{ Deskripsi } \\
\hline & $\begin{array}{l}\text { parkir pada stasiun asal sudah } \\
\text { baik. }\end{array}$ \\
Sumber : Penulis, 2016 & \multicolumn{2}{l}{} \\
\hline \hline
\end{tabular}

Sumber : Penulis, 2016

\section{Identifikasi Karakteristik Perilaku pergerakan komuter yang menggunakan park and ride pada Koridor Bekasi-Jakarta}

Karakteristik sosial-ekonomi adalah latar belakang sosial dan ekonomi komuter yang merupakan menjadi salah satu faktor untuk mempengaruhi komuter dalam memilih moda transportasi pada Koridor Bekasi-Jakarta. Berikut merupakan karakteristik sosial ekonomi komuter pada Koridor Bekasi-Jakarta

Tabel 4.

Karakteristik Sosial-Ekonomi Pengguna Park \& Ride

\begin{tabular}{|c|c|c|}
\hline Variabel & Sub-Variabel & Deskripsi \\
\hline Jenis Kelamin & ( & $\begin{array}{l}\text { Pada Koridor Bekasi Jakarta sebagian } \\
\text { besar pengguna park \& ride }(60,26 \% \\
\text { responden) memiliki jenis kelamin } \\
\text { laki-laki. }\end{array}$ \\
\hline $\begin{array}{l}\text { Tingkat } \\
\text { Pendapatan }\end{array}$ & - & $\begin{array}{l}\text { Sebagian besar responden }(31,79 \%) \\
\text { memiliki pendapatan diatas Rp. } \\
5.200 .000-\text { Rp. } 7.800 .000 \text { per bulan. }\end{array}$ \\
\hline $\begin{array}{l}\text { Tingkat } \\
\text { Pendidikan }\end{array}$ & - & $\begin{array}{l}\text { Sebagian besar responden }(50,33 \%) \\
\text { memiliki latar belakang pendidikan } \\
\text { sarjana strata } 1 \text {. Kesimpulan bahwa } \\
\text { sebagian besar pengguna fasilitas park } \\
\text { \& ride memiliki pendidikan yang baik }\end{array}$ \\
\hline Jenis Pekerjaan & - & $\begin{array}{l}\text { Sebagian besar responden }(39,07 \%) \\
\text { pada Stasiun Bekasi dan Stasiun } \\
\text { Kranji memiliki jenis pekerjaan } \\
\text { pegawai swasta. }\end{array}$ \\
\hline
\end{tabular}

Sumber : Penulis, 2016

Karakteristik perjalanan merupakan sebuah pola pergerakan para komuter untuk mencapai lokasi tujuan. Karakteristik perjalanan terdiri dari tujuan perjalanan, waktu perjalanan, panjang perjalanan, biaya perjalanan, tingkat penggunaan moda transportasi pada daerah tujuan, ketersediaan pedestrian pada stasiun tujuan dan ketersediaan transportasi umum dari stasiun tujuan menuju tujuan akhir. Berikut karakteristik perjalanan para pelaku komuting pada Koridor Bekasi-Jakarta.

Tabel 5.

Karakteristik Perjalanan Pengguna Park \& Ride

\begin{tabular}{|c|c|c|}
\hline $\begin{array}{l}\text { Maksud } \\
\text { Perjalanan }\end{array}$ & Sub-Variabel & $\begin{array}{l}\text { Deskripsi } \\
\text { Sebagian besar pengguna park \& } \\
\text { ride pada Koridor Bekasi-Jakarta } \\
\text { melakukan perjalanan untuk } \\
\text { bekerja }(63,57 \%) \text {. Hal ini sangat } \\
\text { dipengaruhi oleh banyaknya } \\
\text { responden yang memiliki } \\
\text { pekerjaan sebagai pegawai. }\end{array}$ \\
\hline \multirow[t]{3}{*}{$\begin{array}{l}\text { Waktu } \\
\text { Perjalanan }\end{array}$} & $\begin{array}{l}\text { Waktu Menuju } \\
\text { Stasiun Asal }\end{array}$ & $\begin{array}{l}\text { Sebagian besar pelaku komuting } \\
\text { menghabiskan waktu } 15-30 \text { menit } \\
\text { dari tempat tinggal menuju stasiun } \\
\text { asal }(46,35 \%) \text {. }\end{array}$ \\
\hline & $\begin{array}{l}\text { Waktu } \\
\text { Perjalanan } \\
\text { Moda KRL }\end{array}$ & $\begin{array}{l}\text { Sebagian besar responden } \\
\text { menghabiskan waktu } 45 \text { menit } \\
\text { dari stasiun asal menuju stasiun } \\
\text { pemberhentian sepanjang Koridor } \\
\text { Bekasi-Jakarta }(38,41 \%) \text {. }\end{array}$ \\
\hline & Waktu Menuju & Sebagian besar pengguna park \& \\
\hline
\end{tabular}

\begin{tabular}{|c|c|c|}
\hline Variabel & $\begin{array}{l}\text { Sub-Variabel } \\
\text { Lokasi Tujuan }\end{array}$ & \begin{tabular}{l}
\multicolumn{1}{c}{ Deskripsi } \\
ride pada Koridor Bekasi-Jakarta \\
memerlukan waktu kurang dari 5 \\
menit dari stasiun pemberhentian \\
menuju lokasi tujuan $(30,46 \%)$.
\end{tabular} \\
\hline & Jarak Menuju & Sebagian besar responden \\
\hline \multirow[t]{3}{*}{$\begin{array}{l}\text { Panjang } \\
\text { Perjalanan }\end{array}$} & Stasiun Asal & $\begin{array}{l}\text { menempuh jarak kurang dari } 7 \mathrm{~km} \\
\text { dari tempat tinggal untuk } \\
\text { mencapai stasiun asal }(61,58 \%)\end{array}$ \\
\hline & $\begin{array}{l}\text { Jarak Tempuh } \\
\text { KRL }\end{array}$ & $\begin{array}{l}\text { Sebagian besar komuter menepuh } \\
\text { jarak } 17-23 \mathrm{~km} \text { dari stasiun asal } \\
\text { menuju stasiun pemberhentian } \\
(60,26 \%) \text {. }\end{array}$ \\
\hline & $\begin{array}{l}\text { Jarak Menuju } \\
\text { Lokasi Tujuan }\end{array}$ & $\begin{array}{l}\text { Dapat disimpulkan bahwa } \\
\text { sebagian besar responden } \\
\text { menempuh jarak yang cukup } \\
\text { dekat yaitu kurang dari } 7 \mathrm{~km} \text { dari } \\
\text { stasiun berhenti menuju lokasi } \\
\text { tujuan }(67,55 \%) \text {. }\end{array}$ \\
\hline \multirow[t]{2}{*}{ Perjalanan } & - & $\begin{array}{l}\text { Dapat disimpulkan bahwa } \\
\text { sebagian besar responden } \\
\text { mengeluarkan biaya perjalanan } \\
\text { sebesar Rp. } 10.751 \text {-Rp. } 21.500 \\
\text { per hari }(38,41 \%)\end{array}$ \\
\hline & & $\begin{array}{l}\text { Dapat disimpulkan bahwa } \\
\text { ketersediaan moda alternative } \\
\text { pada stasiun pemberhentian di }\end{array}$ \\
\hline \multirow{3}{*}{$\begin{array}{l}\text { Jumlah Moda } \\
\text { Transportasi } \\
\text { Umum yang } \\
\text { Tersedia }\end{array}$} & - & $\begin{array}{l}\text { Koridor Bekasi-Jakarta sudah } \\
\text { baik karena sebagian besar } \\
\text { responden }\end{array}$ \\
\hline & & $\begin{array}{l}\text { ketersediaan moda transportasi } \\
\text { pada stasiun tujuan sudah baik } \\
(50,33 \%) \text {. }\end{array}$ \\
\hline & & $\begin{array}{l}\text { Dapat disimpulkan bahwa pilihan } \\
\text { moda sebagian besar para } \\
\text { pengguna park \& ride dari stasiun }\end{array}$ \\
\hline \multirow[t]{2}{*}{$\begin{array}{l}\text { Penggunaan } \\
\text { Moda Pada } \\
\text { Stasiun } \\
\text { Pemberhentian }\end{array}$} & - & $\begin{array}{l}\text { tujuan adalah berjalan kaki } \\
(39,73 \%) \text {. Selain berjalan kaki, } \\
\text { banyak para pengguna park \& } \\
\text { ride yang memilih angkutan } \\
\text { umum untuk mencapai lokasi } \\
\text { tujuan }(36,42 \%) \text {. }\end{array}$ \\
\hline & $\begin{array}{l}\text { Ketersediaan } \\
\text { Pedestrian } \\
\text { Way }\end{array}$ & $\begin{array}{l}\text { Sebagian besar responden } \\
(90,06 \%) \text { berpendapat bahwa } \\
\text { pada setiap stasiun tujuan pada }\end{array}$ \\
\hline \multirow[t]{3}{*}{$\begin{array}{l}\text { Pedestrian Way } \\
\text { (pada stasiun } \\
\text { pemberhentian) }\end{array}$} & & $\begin{array}{l}\text { Koridor Bekasi-Jakarta sudah } \\
\text { tersedia pedestran way. Dapat } \\
\text { disimpulkan bahwa hampir } \\
\text { seluruh stasiun tujuan pada } \\
\text { Koridor Bekasi-Jakarta sudah } \\
\text { tersedia pedestran way. }\end{array}$ \\
\hline & $\begin{array}{l}\text { Kondisi } \\
\text { Pedestrian }\end{array}$ & $\begin{array}{l}\text { Dapat disimpulkan bahwa kondisi } \\
\text { pedestran way yang tersedia pada }\end{array}$ \\
\hline & Way & $\begin{array}{l}\text { stasiun tujuan dalam kondisi yang } \\
\text { baik. Hal ini memberikan } \\
\text { kenyamanan bagi para komuter } \\
\text { untuk melakukan pergerakan } \\
(45,03 \%) \text {. }\end{array}$ \\
\hline
\end{tabular}

Sumber : Penulis, 2016

\section{E. Analisis Faktor-Faktor yang Mempengaruhi Penggunaan Park \& Ride sebagai Prasarana Pendukung Pergerakan Pada Koridor Bekasi-Jakarta}

Berdasarkan hasil teknik analisis crosstab dan korelasi bivariat, dari 23 faktor yang dianalisis, sebanyak 10 faktor yang memiliki keterkaitan dengan frekuensi penggunaan park \& ride. Tahap selanjutnya adalah melihat nilai korelasi setiap faktor yang memiliki hubungan dengan frekuensi penggunaan park \& ride. Berikut tabel tingkat kekuatan hubungan masing-masing faktor yang mempengaruhi penggunaan fasilitas park \& ride: 
Tabel 6.

Rumusan Faktor-Faktor yang Mempengaruhi Penggunaan Park \& Ride

\begin{tabular}{|c|c|c|c|}
\hline Faktor & $\begin{array}{c}\text { Nilai } \\
\text { Signifikansi }\end{array}$ & $\begin{array}{c}\text { Nilai } \\
\text { Korelasi }\end{array}$ & $\begin{array}{l}\text { Pengaruh Faktor Terhadap } \\
\text { Pemilihan Park \& Ride }\end{array}$ \\
\hline $\begin{array}{l}\text { Biaya } \\
\text { Parkir }\end{array}$ & 0,017 & 0,305 & $\begin{array}{l}\text { Biaya parkir memiliki } \\
\text { pengaruh signifikansi } \\
\text { terhadap pemilihan park \& } \\
\text { ride dengan tingkat pengaruh } \\
\text { sebesar } 0,305 \text { (rendah). Hal } \\
\text { ini ditinjau berdasarkan } \\
\text { sebagian besar responden } \\
\text { yang membayar parkir kurang } \\
\text { dari Rp. 5000 (38,41\%). } \\
\text { Semakin sering frekuensi } \\
\text { penggunaan park \& ride, } \\
\text { maka akan semakin murah } \\
\text { biaya parkir yang dipilih. }\end{array}$ \\
\hline $\begin{array}{l}\text { Lama } \\
\text { Parkir }\end{array}$ & 0,000 & 0,442 & $\begin{array}{l}\text { Lama parkir merupakan salah } \\
\text { satu faktor yang memiliki } \\
\text { pengaruh signifikansi } \\
\text { terhadap pemilihan park \& } \\
\text { ride sebesar } 0,442 \text { (sedang). } \\
\text { Hal ini dapat dilihat dari } \\
\text { banyaknya pelaku komuting } \\
\text { yang memarkirkan kendaraan } \\
\text { selama } 7-12 \text { jam }(74,14 \%) \text {. }\end{array}$ \\
\hline $\begin{array}{l}\text { Kenyama } \\
\text { nan } \\
\text { Fasilitas } \\
\text { Parkir }\end{array}$ & 0,040 & 0,311 & $\begin{array}{l}\text { Faktor selanjutnya yang } \\
\text { memiliki pengaruh terhadap } \\
\text { pemilihan park \& ride adalah } \\
\text { kenyamanan parkir dengan } \\
\text { nilai signifikansi sebesar } \\
0,311 \text { (rendah). Hal ini dapat } \\
\text { dilihat dari sebagian besar } \\
\text { responden (50,99\%) yang } \\
\text { berpendapat } \\
\text { kenyamanan fasilitas } \\
\text { sudah parkir cukup baik. } \\
\text { Lengkapnya fasilitas parkir } \\
\text { membantu park \& ride untuk } \\
\text { mempengaruhi pengguna } \\
\text { kendaraan pribadi beralih } \\
\text { menggunakan } \\
\text { transportasi KRL. }\end{array}$ \\
\hline $\begin{array}{l}\text { Jenis } \\
\text { Pekerjaan }\end{array}$ & 0,000 & 0,483 & $\begin{array}{lr}\text { Satu-satunya } & \text { karakteristik } \\
\text { sosial-ekonomi } & \text { yang } \\
\text { mempengaruhi pemilihan } \\
\text { park \& ride adalah faktor } \\
\text { jenis pekerjaan. Faktor jenis } \\
\text { pekerjaan memiliki pengaruh } \\
\text { signifikansi } \quad \text { terhadap } \\
\text { pemilihan park \& ride sebesar } \\
0,483 \text { (sedang). Pekerjaan } \\
\text { para pengguna park \& ride } \\
\text { didominasi oleh pegawai } \\
\text { swasta }(39,07 \%) \text {. }\end{array}$ \\
\hline $\begin{array}{l}\text { Maksud } \\
\text { Perjalana } \\
\text { n }\end{array}$ & 0,000 & 0,529 & $\begin{array}{l}\text { Maksud perjalanan } \\
\text { merupakan faktor yang paling } \\
\text { berpengaruh } \\
\text { pemilihan terhadap } \\
\text { diantara faktor-faktor yang } \\
\text { lain yaitu sebesar } 0,529 \\
\text { (sedang). Artinya park \& ride } \\
\text { digunakan oleh pelaku } \\
\text { komuter dengan segmen } \\
\text { tertentu yaitu komuter yang } \\
\text { bekerja menuju pusat kota } \\
(63,57 \%) \text {. }\end{array}$ \\
\hline $\begin{array}{l}\text { Waktu di } \\
\text { KRL }\end{array}$ & 0,000 & 0,309 & $\begin{array}{l}\text { Faktor waktu perjalanan } \\
\text { terutama pada saat berada di } \\
\text { moda KRL menjadi salah satu } \\
\text { faktor yang mempengaruhi } \\
\text { pemilihan park \& ride yaitu } \\
\text { dengan nilai korelasi sebesar } \\
0,309 \text { (sedang). Hal ini }\end{array}$ \\
\hline
\end{tabular}

\begin{tabular}{|c|c|c|c|}
\hline Faktor & $\begin{array}{c}\text { Nilai } \\
\text { Signifikansi }\end{array}$ & $\begin{array}{c}\text { Nilai } \\
\text { Korelasi }\end{array}$ & $\begin{array}{c}\text { Pengaruh Faktor Terhadap } \\
\text { Pemilihan Park \& Ride }\end{array}$ \\
\hline $\begin{array}{l}\text { Jarak } \\
\text { Menuju } \\
\text { Stasiun }\end{array}$ & 0,012 & 0,204 & $\begin{array}{l}\text { disebabkan karena proporsi } \\
\text { perjalanan komuter pada saat } \\
\text { berada di KRL paling besar } \\
\text { diantara saat berada di moda } \\
\text { lainnya. } \\
\text { Faktor jarak stasiun asal } \\
\text { menjadi salah satu faktor yang } \\
\text { mempengaruhi pemilihan } \\
\text { park \& ride dengan nilai } \\
\text { korelasi sebesar 0,204 } \\
\text { (rendah). Semakin dekat letak } \\
\text { stasiun asal dengan tempat } \\
\text { tinggal pelaku komuting, } \\
\text { semakin optimal peran park \& } \\
\text { ride untuk menarik pelaku } \\
\text { komuting menggunakan } \\
\text { moda transportasi KRL untuk } \\
\text { menuju pusat kota. Hal ini } \\
\text { dapat dilihat dari sebagian } \\
\text { besar pengguna park \& ride } \\
\text { yang memiliki tempat tinggal } \\
\text { di dekat stasiun asal (61,58\%) }\end{array}$ \\
\hline $\begin{array}{l}\text { Jarak } \\
\text { KRL }\end{array}$ & 0,007 & 0,219 & $\begin{array}{l}\text { Sama seperti faktor waktu di } \\
\text { KRL, faktor jarak pada saat } \\
\text { berada di KRL memiliki } \\
\text { pengaruh terhadap pemilihan } \\
\text { park \& ride dengan nilai } \\
\text { korelasi sebesar 0,219 } \\
\text { (rendah). Hal ini disebabkan } \\
\text { jarak yang ditempuh moda } \\
\text { KRL berkontribusi besar } \\
\text { terhadap panjang perjalanan } \\
\text { para komuter. }\end{array}$ \\
\hline $\begin{array}{l}\text { Biaya } \\
\text { Perjalana } \\
\mathrm{n}\end{array}$ & 0,008 & $-0,214$ & $\begin{array}{l}\text { Biaya perjalanan merupakan } \\
\text { salah satu faktor yang } \\
\text { mempengaruhi pemilihan } \\
\text { park \& ride dengan nilai } \\
\text { korelasi sebesar 0,214 } \\
\text { (rendah). Hal ini dapat dilihat } \\
\text { dari banyaknya jumlah } \\
\text { responden } y \text { yang } \\
\text { mengeluarkan biaya parkir } \\
\text { sebesar Rp. 10.750- Rp. Rp. } \\
\text { 21.500. nilai korelasi minus } \\
\text { artinya semakin sering } \\
\text { frekuensi penggunaan park \& } \\
\text { ride, maka akan semakin } \\
\text { murah biaya perjalanannnya. }\end{array}$ \\
\hline $\begin{array}{l}\text { Pengguna } \\
\text { an Moda } \\
\text { Pada } \\
\text { Stasiun } \\
\text { Pemberhe } \\
\text { ntian }\end{array}$ & 0,038 & 0,285 & $\begin{array}{lr}\text { Faktor terakhir yang } \\
\text { mempengaruhi penggunaan } \\
\text { park \& ride adalah } \\
\text { penggunaan moda pada } \\
\text { stasiun pemberhentian dengan } \\
\text { nilai korelasi sebesar } 0,285 \\
\text { (rendah). Terdapat pola } \\
\text { pengguna park \& ride } \\
\text { cenderung memilih moda } \\
\text { transportasi yang murah. Hal } \\
\text { ini dapat dilihat dari } \\
\text { banyaknya jumlah responden } \\
\text { yang berjalan kaki untuk } \\
\text { mencapattujuan akhir } \\
(39,73 \%) \text {. }\end{array}$ \\
\hline
\end{tabular}

Sumber : Penulis, 2016

Dari 10 faktor yang mempengaruhi pelaku komuting menggunakan park \& ride, berdasarkan nilai korelasinya faktor maksud perjalanan memiliki pengaruh yang paling kuat. Pemilihan park \& ride dominan terlihat pada perjalanan dengan maksud bekerja. Artinya karakteristik perjalanan di 
wilayah pinggiran menuju pusat kota mempengaruhi pemilihan park \& ride sebagai fasilitas penunjang pergerakan.

\section{KESIMPULAN}

Dari hasil pembahasan penentuan faktor-faktor yang mempengaruhi penggunaan fasilitas park \& ride pada Koridor Bekasi-Jakarta, dapat disimpulkan bahwa:

1. Karakteristik parkir yang mempengaruhi frekuensi penggunaan fasilitas park \& ride pada Koridor Bekasi-Jakarta adalah faktor biaya parkir, lama parkir, dan kenyamanan fasilitas parkir

2. Karakteristik sosial-ekonomi yang mempengaruhi frekuensi penggunaan fasilitas park $\&$ ride pada Koridor Bekasi-Jakarta adalah faktor jenis pekerjaan.

3. Karakteristik perjalanan yang mempengaruhi frekuensi penggunaan fasilitas park \& ride pada Koridor Bekasi-Jakarta adalah faktor maksud perjalanan, waktu tempuh KRL, jarak tempat tinggal menuju stasiun asal, jarak tempuh KRL, biaya perjalanan dan penggunaan moda transportasi pada stasiun pemberhentian.

4. Faktor yang memiliki hubungan korelasi yang paling kuat dengan frekuensi penggunaan fasilitas park \& ride adalah faktor maksud perjalanan komuter.

\section{DAFTAR PUSTAKA}

[1] Alyia, Sharifah Adibah (2013). Evaluating the Parking Demand at Park and ride Facility at Putrajaya Public Transportation Terminal. Journal, International Islamic University Malaysia. Kuala Lumpur. Antariksa. (2010).

[2] Badan Pusat Statistik Kota Bekasi. 2015. Statistik Komuter Kota Bekasi Tahun 2014. Kota Bekasi : BPS

[3] Badan Pusat Statistik Provinsi DKI Jakarta. Komuter DKI Jakarta Tahun 2014. Provinsi DKI Jakarta : BPS

[4] Damanik, R. (2006). Analisis Manfaat bagi Pengguna Sistem Park \& Ride Sepeda Motor di jabodetabek. Tesis Program Magister Bidang Ilmu Teknik: Universitas Indonesia

[5] Erli, Ketut Dewi Martha. (2009) The Relevance Of Urban Form As Determinant Of Travel Behavior Change In Indonesian Neighborhood Level. Jurnal. Institut Teknologi Sepuluh Nopember.

[6] Guntur, Andi (2014). Fasilitas Park and ride Sebagai Bagian dari Pelayanan Kereta Api Perkotaan (Studi Kasus: Kereta Api Perkotaan Bandung., Jurnal.Institut Teknologi Bandung. Bandung.

[7] Hamid, Norlida Abdul (2008). Travel behavior of the Park and ride users and the factors influencing the demand for the use of the Park and ride facility. Universiti Teknologi Malaysia. Johor.

[8] Hole, Arne Risa. (2004). Forecasting the demand for an employee Park and ride service using commuters' stated choices.University of St Andrews. Scotland.

[9] Islam, Shahi Tapshsir (2015). Exploring the Mode Change Behavior of Park-and-Ride Users. Research Article. Hindawi.

[10] Limaryantamarico. (2015). Analisis Kebutuhan Park and ride BRT Trans Musi Pada Kawasan Seberang Ulu Palembang. Jurnal. Universitas Lampung. Lampung.

[11] Miro, Fidel, 2002, Perencanaan Transportasi, Erlangga, Jakarta

[12] Olsson, Anna-Lena. (2003). Factor That Influence Choice of Travel Mode in Major Urban Areas "The attractiveness of Park \& Ride". Division of Transportation and Logistic.

[13] South Yorkshire Passenger Transport Authority, (2012), Park \& Ride Strategy 2006-2011.

[14] Spillar, Robert J (1997). Park and ride Planning and Design Guideline, Parsons Brinckerhoff inc.

[15] Tamin, Ofyar Z, 2000, Perencanaan dan Pemodelan Transportasi, ITB,Bandung

[16] Vincent, Mike. (2007). Park and ride: Characteristics and demand forecasting. Land Transport New Zealand. 